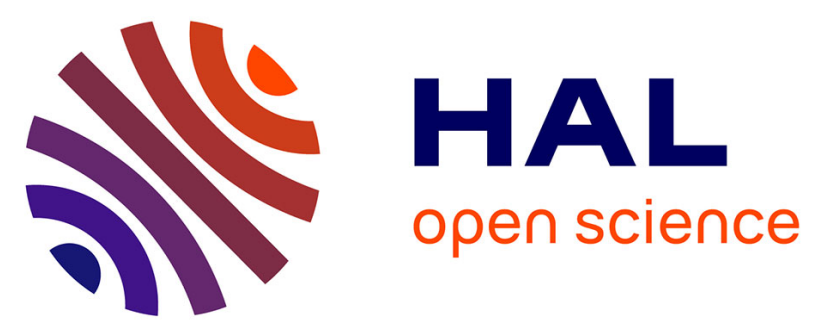

\title{
Serum level of soluble triggering receptor expressed on myeloid cells-1 (sTREM-1) is a biomarker of synovitis in rheumatoid arthritis
}

Clémence Gorlier, Jacques-Eric Gottenberg, Ludivine Laurans, Tabassome Simon, Hafid Ait-Oufella, Jérémie Sellam

\section{To cite this version:}

Clémence Gorlier, Jacques-Eric Gottenberg, Ludivine Laurans, Tabassome Simon, Hafid Ait-Oufella, et al.. Serum level of soluble triggering receptor expressed on myeloid cells-1 (sTREM-1) is a biomarker of synovitis in rheumatoid arthritis. International Journal of Rheumatic Diseases, 2019, 22 (9), pp.1616-1618. 10.1111/1756-185X.13656 . hal-02291828

\section{HAL Id: hal-02291828 \\ https://hal.sorbonne-universite.fr/hal-02291828}

Submitted on 19 Sep 2019

HAL is a multi-disciplinary open access archive for the deposit and dissemination of scientific research documents, whether they are published or not. The documents may come from teaching and research institutions in France or abroad, or from public or private research centers.
L'archive ouverte pluridisciplinaire HAL, est destinée au dépôt et à la diffusion de documents scientifiques de niveau recherche, publiés ou non, émanant des établissements d'enseignement et de recherche français ou étrangers, des laboratoires publics ou privés. 
Serum level of soluble triggering receptor expressed on myeloid cells-1 (sTREM-1) is a biomarker of synovitis in rheumatoid arthritis

Clémence Gorlier (1, 2), Jacques-Eric Gottenberg (3), Ludivine Laurans (4), Tabassome Simon (5), Hafid Ait Oufella* (4), Jérémie Sellam* $(1,2,6)$

1. Assistance Publique - Hôpitaux de Paris (AP-HP), Saint-Antoine hospital, Rheumatology department, DHU-i2B, 75012, Paris France

2. Sorbonne Université, 75012, Paris, France

3. Strasbourg University Hospital, Rheumatology department, 67000 Strasbourg, France

4. Inserm U970, Paris Cardiovascular Research Center, 75015 Paris, France; Université René Descartes, Paris, France.

5. AP-HP, Saint-Antoine Hospital, Plateforme de Recherche Clinique de l'Est Parisien (URCESTCRCEST-CRB), 75012 Paris, France

6. Centre de Recherche Saint-Antoine, Inserm UMRS_938, 75012 Paris, France

* Both authors contributed equally to this work

Keywords: TREM-1, disease activity, biomarkers, rheumatoid arthritis, biologic agent

Word count: 596

Number of figure: 1

Number of table: 1

\section{Correspondence to:}

Prof. Jérémie Sellam, MD, PhD

Rheumatology Department, Saint-Antoine Hospital

184, rue du Faubourg Saint-Antoine

75012 Paris, FRANCE

Tel: + 33149282520

Fax : + 33149282513

jeremie.sellam@aphp.fr 
Triggering Receptor Expressed on Myeloid cells-1 (TREM-1) is a receptor mainly expressed on monocytes and neutrophils, involved in the amplification of the immune response during both bacteria and sterile inflammation [1]. Following engagement, TREM-1 is shed and may be detected in the blood. In patients admitted for myocardial infarction, plasma levels of soluble TREM-1 (sTREM-1) has been identified as an independent predictor of ischemia recurrence and death.[2] In rheumatoid arthritis (RA), TREM-1 is over-expressed in synovial tissues and its pharmacological inhibition limits destructive lesions of collagen-induced arthritis [3,4]. Few works suggested that serum sTREM-1 level may reflect RA disease activity, but they included small sample size of patients and the association between serum sTREM-1 level and subsequent treatment response has never been addressed [5,6]. Therefore, we aimed to investigate whether STREM-1 serum level is associated with disease activity and/or can predict response to biologic agent in RA patients. This is an ancillary study of the Rotation or Change trial (NCT NCT01000441) in which 300 RA patients with an inadequate response to a $1^{\text {st }}$ line anti- TNFa agent were randomized to switch to either a $2^{\text {nd }}$ anti- TNFa or a non-anti- TNFa agent [7]

Baseline serum STREM-1 level was assessed in 272 patients with available serum samples using enzyme-linked immunosorbent assay (ELISA) (Quantikine, R\&D Systems, Lille, France). The characteristics of the patients are reported in the Table 1. Among the patients assigned to the second anti-TNFa group, 106/133 patients (79.7\%) received a concomitant synthetic DMARD and 68/133 (51.1\%) received concomitant oral corticosteroids with a mean (SD) dose of 7.3 (3.0)mg/d. Among the patients assigned to the non-anti-TNFa group 102/139 (73.4\%) received a concomitant synthetic DMARD and 77/139 (55.4\%) received concomitant oral corticosteroids with a mean dose of 7.4 (2.9) $\mathrm{mg} / \mathrm{d}$, all $\mathrm{p}>0.05$. Good or moderate EULAR response at week 24 (W24) was achieved in 51.9\% patients in the $2^{\text {nd }}$ anti- TNFa group vs $66.9 \%$ patients in the non-anti- TNFa group $(p=0.01)$.

Serum STREM-1 level was detectable in all patients (mean level (standard deviation) 471.1 (242.0) $\mathrm{pg} / \mathrm{mL})$. STREM-1 level was higher in men when compared to women (585.0 (240.1) pg/mL versus 447.9 (236.3) $\mathrm{pg} / \mathrm{mL}, \mathrm{p}=0.0004$ ), but was not associated with seropositivity status nor correlated with body mass index. Serum sTREM-1 levels was higher in patients with DAS28-CRP>5.1 (542.5 (279.6) pg/mL) than in those with DAS28-CRP $\leq 5.1$ (433.3 (212.5) pg/mL; $p<0.01)$ (non-parametric Wilcoxon test). Such a result persisted after adjusting for sex $(p=0.005)$. Using Spearman coefficients, we found that STREM1 level was positively correlated with DAS28-CRP value $(r=0.25, p<0.001)$ (Figure 1 A), due to its correlation with CRP level $(r=0.38, p<0.0001)$, but also to specific assessments of RA (patient global 
assessment $r=0.14$ and swollen joint count $r=0.20, p<0.05$ ) (Figure 1B). sTREM-1 level was still significantly associated with swollen joint count after adjustment on CRP level in a regression analysis model $(\beta=0.017, p=0.008)$.

Concerning the association with clinical response at W24, mean baseline STREM-1 levels did not differ between W24 good and moderate EULAR responders versus non-responders in the whole population (459.9 (217.0) versus $487.6(275.0) \mathrm{pg} / \mathrm{mL}, \mathrm{p}>0.05)$. Similar results were obtained in the $2^{\text {nd }}$ anti- TNFa group (450.8 (210.2) versus 502.7 (291.6) pg/mL, p>0.05) as well as in the non-anti- TNFa group (466.7 (22.7) versus $466.6(251.7) \mathrm{pg} / \mathrm{mL}, \mathrm{p}>0.05)$.

In conclusion, serum STREM-1 level may be a new interesting marker for RA disease activity. Serum sTREM-1 level does not only reflect systemic inflammation (i.e., CRP level) but also clinical joint inflammation, suggesting a specific role of this myeloid receptor in rheumatoid synovitis pathophysiology. Along this line, longitudinal assessment of serum STREM-1 before and after treatment would be interesting

\section{References:}

1. Tammaro A, Derive M, Gibot S, Leemans JC, Florquin S, Dessing MC. TREM-1 and its potential ligands in non-infectious diseases: from biology to clinical perspectives. Pharmacology \& Therapeutics. sept 2017;177:81-95.

2. Boufenzer $A$, Lemarie J, Simon $T$, Derive $M$, Bouazza $Y$, Tran N, et al. TREM-1 Mediates Inflammatory Injury and Cardiac Remodeling Following Myocardial Infarction. Circulation Research. 22 mai 2015;116(11):1772-82.

3. Kuai J, Gregory B, Hill A, Pittman DD, Feldman JL, Brown T, et al. TREM-1 expression is increased in the synovium of rheumatoid arthritis patients and induces the expression of proinflammatory cytokines. Rheumatology. 1 nov 2009;48(11):1352-8.

4. Murakami $\mathrm{Y}$, Akahoshi T, Aoki N, Toyomoto M, Miyasaka N, Kohsaka H. Intervention of an inflammation amplifier, triggering receptor expressed on myeloid cells 1 , for treatment of autoimmune arthritis. Arthritis \& Rheumatism. juin 2009;60(6):1615-23.

5. Molad Y, Ofer-Shiber S, Pokroy-Shapira E, Oren S, Shay-Aharoni H, Babai I. Soluble triggering receptor expressed on myeloid cells-1 is a biomarker of anti-CCP-positive, early rheumatoid arthritis. European Journal of Clinical Investigation. juin 2015;45(6):557-64.

6. Choi ST, Kang E-J, Ha YJ, Song J-S. Levels of Plasma-soluble Triggering Receptor Expressed on Myeloid Cells-1 (sTREM-1) Are Correlated with Disease Activity in Rheumatoid Arthritis. The Journal of Rheumatology. 1 mai 2012;39(5):933-8.

7. Gottenberg J-E, Brocq O, Perdriger A, Lassoued S, Berthelot J-M, Wendling D, et al. Non-TNFTargeted Biologic vs a Second Anti-TNF Drug to Treat Rheumatoid Arthritis in Patients With Insufficient Response to a First Anti-TNF Drug: A Randomized Clinical Trial. JAMA. 20 sept 2016;316(11):1172-80. 


\section{Acknowledgements}

The authors thank all patients for participating in this study, Pr Philippe Ravaud, MD, PhD (Paris, France), Alexandra Rousseau (URCEST, Paris, France) and all investigators who included patients in the ROC study : Olivier Brocq, MD; Aleth Perdriger, MD; Slim Lassoued, MD; Jean-Marie Berthelot, MD; Daniel Wendling, MD, PhD; Liana Euller-Ziegler, MD; Martin Soubrier, MD; Christophe Richez, MD, PhD; Bruno Fautrel, MD, PhD; Arnaud Constantin, MD, PhD; Jacques Morel, MD, PhD; Melanie Gilson, MD; Gregoire Cormier, MD; Jean Hugues Salmon, MD; Stephanie Rist, MD; Frederic Lioté, MD, PhD; Hubert Marotte, MD, PhD; Christine Bonnet, MD; Christian Marcelli, MD, PhD; Olivier Meyer, MD, PhD; Elisabeth Solau-Gervais, MD, PhD; Sandrine Guis, MD, PhD; Jean-Marc Ziza, MD; Charles Zarnitsky, MD; Isabelle Chary-Valckenaere, MD, PhD; Olivier Vittecoq, MD, PhD; Alain Saraux, MD, PhD; YvesMarie Pers, MD, PhD; Martine Gayraud, MD; Gilles Bolla, MD; Pascal Claudepierre, MD, PhD; Marc Ardizzone, MD; Emmanuelle Dernis, MD; Maxime A. Breban, MD, PhD; Olivier Fain, MD, PhD; JeanCharles Balblanc, MD; Ouafaa Aberkane, PhD; Marion Vazel, PhD; Christelle Back, PhD; Sophie Candon, MD, PhD; Lucienne Chatenoud, MD, PhD; Elodie Perrodeau, MSc; Jean Sibilia, MD

\section{Fundings}

The main ROC study was sponsored by the French Ministry of Health (Programme Hospitalier de Recherche Clinique National 2009/4507 EUDRACT No: 2009-013482-26) and promoted by The Direction de la Recherche Clinique et de l'Innovation, Strasbourg University Hospital. The funding agency had no role in the design and conduct of the study; collection, management, analysis, and interpretation of the data; the decision to submit for publication or preparation, review, or approval of the manuscript for publication. This ancillary study was sponsored by the Assistance Publique - Hôpitaux de Paris (AP-HP) (Fond d'amorçage 2016).

\section{Conflict of interest: none}


Figure 1. Correlation of serum STREM-1 levels with disease activity features in 272 patients with rheumatoid arthritis and insufficient response to a first anti-TNF therapy

1A. Correlation between serum sTREM-1 levels and DAS28-CRP values

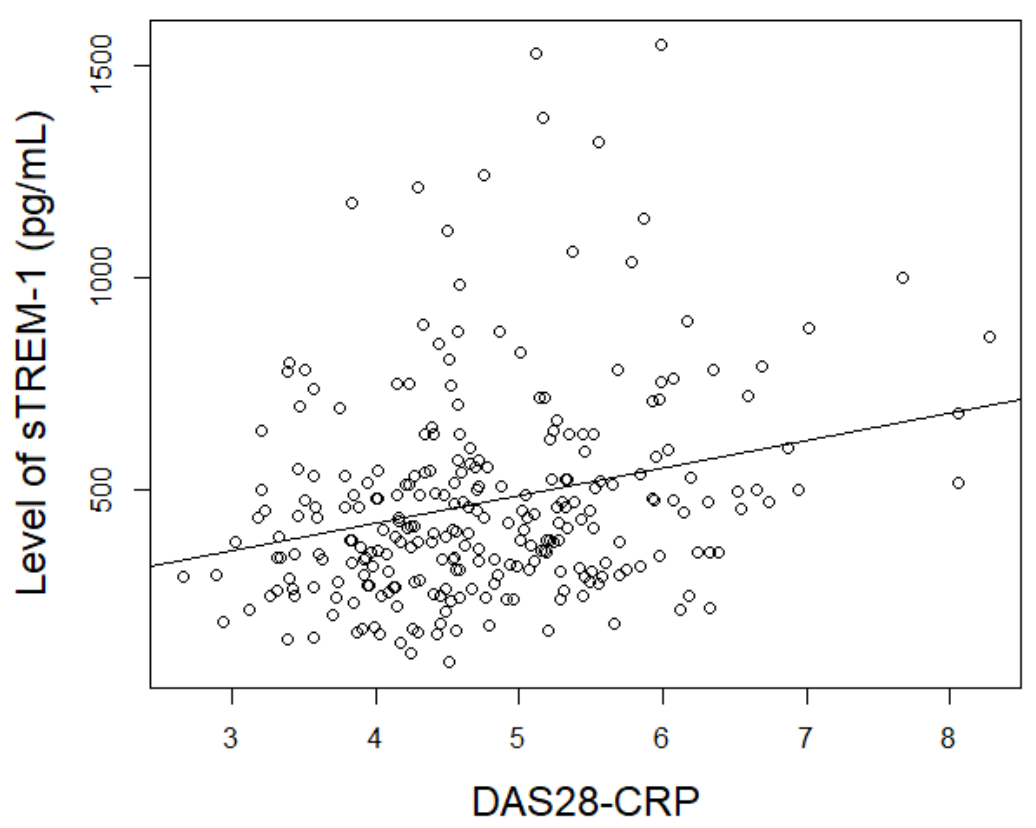

1B. Correlation between serum sTREM-1 levels and 28-Swollen Joint Count

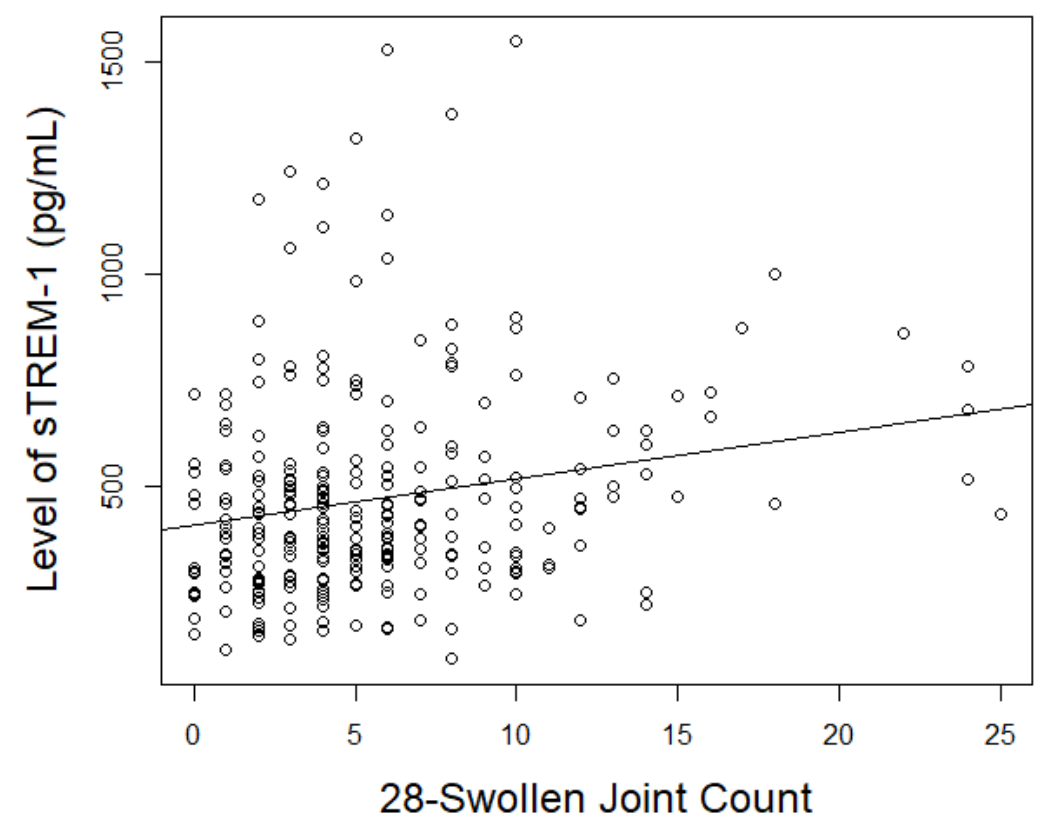

STREM-1: soluble Triggering Receptor Expressed on Myeloid cells-1; DAS28-CRP: Disease Activity Score 28-C reactive protein; TNF : Tumor Necrosis Factor.

STREM-1 level was positively correlated with DAS28-CRP value $(r=0.25, p<0.001)(1 \mathrm{~A})$ and also to specific assessments of rheumatoid arthritis as swollen joint count $(r=0.20, p<0.05)(1 B)$. 